\title{
Cultural Work as a Site of Struggle: Freelancers and Exploitation
}

\author{
Nicole S. Cohen
}

\author{
York University, Toronto, Canada, nscohen@yorku.ca
}

\begin{abstract}
This paper argues that Marxist political economy is a useful framework for understanding contemporary conditions of cultural work. Drawing on Karl Marx's foundational concepts, labour process theory, and a case study of freelance writers, I argue that the debate over autonomy and control in cultural work ignores exploitation in labour-capital relationships, which is a crucial process shaping cultural work. To demonstrate the benefits of this approach, I discuss two methods media firms use to extract surplus value from freelance writers: exploitation of unpaid labour time and exploitation of intellectual property through aggressive copyright regimes. I argue that a Marxist perspective can uncover the dynamics that are transforming cultural industries and workers' experiences. From this perspective, cultural work is understood as a site of struggle.
\end{abstract}

Keywords: Cultural work, Marx, political economy, freelancers, exploitation, labour process, copyright, precarity

Acknowledgements: Thank you to the reviewers for valuable comments and to Stephanie Ross, Leah Vosko, Patricia Mazepa, Greig de Peuter, and Matt Carrington for feedback on various versions of this paper.

\section{Introduction: Missing Marx}

Although once considered a blind spot of communication studies (Mosco and McKercher 2006, 493), cultural work has become a growing site of inquiry as scholars from a range of perspectives consider the work that goes into producing media, culture, and communication. ${ }^{1}$ Marx, however, is largely missing from these studies. On the surface, Marx's inquiry into the characteristics of nineteenth-century industrialized production seems an outdated approach for understanding cultural work in the post-Fordist era. In Capital ([1867] 1990), Marx described conditions on the factory floor: the wage labourer with nothing to sell but that most peculiar of commodities, labour power, enters into a "free" relationship of exploitation with an employer, who sets the worker to work. Under the capitalist's control, the worker toils for a long stretch of the day. After earning more than what is necessary to reproduce her labour power, she generates surplus value, or profit, for capital. In the process, the worker becomes part of a generalized class of labourers. Her concrete labour is made abstract as it is sunk into standardized commodity production. Marx describes a subjugated, alienated worker who is interchangeable with other workers, rendered an anonymous input for production.

As work has moved out of the physical factory and into the studios, offices, and home-based workplaces of the creative economy, Marx's account has either been ignored or deemed outmoded. In many cases, cultural workers are understood to be unique kinds of workers and cultural work radically different from other kinds of work, removed from traditional labour-capital antagonisms (Caves 2000; Florida 2002; Deuze 2007; Christopherson 2009). In more critical accounts, Marx is dismissed as reductive because he does not attend to workers' agency or subjectivity (Banks 2007; Conor 2010; Hesmondhalgh and Baker 2011). The most prevalent critique is of Marx's theory of

\footnotetext{
${ }^{1}$ Definitions are contentious in studies of work and labour in the communication and cultural industries. In this paper, by cultural workers, I refer to people who work in the cultural industries, or those industries that generate and circulate commodities that "influence on our understanding of the world" and "produce social meaning" (Hesmondhalgh 2007, 3, 12). Banks $(2007,2)$ defines the cultural industries as 'those involved in the production of 'aesthetic' or 'symbolic' goods and services; that is, commodities whose core value is derived from their function as carriers of meaning in the form of images, symbols, signs and sounds". I use the term culture in order to speak to the issues that arise from the association of this work with creativity and art. Precisely which sectors count as cultural industries varies. Statistics Canada (2012), for example, includes a range of occupations, from librarians and curators to writers, artists, and technical occupations in film and broadcasting. This perspective, while still somewhat broad, is useful because it views the character of cultural work through an understanding of the specificities of the industries in which it is performed rather than through the content of the work. There is something distinctive about cultural goods and their consumption that can explain why cultural production is organized in particular ways (Hesmondhalgh 2007, 101; Miège 1989; Garnham 1997). This avoids, for example, attributing experiences of cultural workers to personal character traits, which is part of the argument I develop in this paper. The term "creative labour", for example, draws attention to qualities specific to a person (Smith and McKinlay 2009a, 3), whereas I argue that the organization of cultural production has a structural effect on workers' experiences, and freelance writers' labour experiences flow directly from the logics of the industry in which they work.
} 
alienation, which describes the worker as separated from control of the labour process, from the products she creates, from other workers, and from her own human essence (Marx [1844] 1978a). For example, Mark Banks $(2007,11)$ critiques a vision of cultural workers as "condemned to serve as alienated labour [...] assumed to be devoid of active subjectivity and suppressed 'from above' by managers and owners." Cultural work is more often described as the antithesis of alienation: as social and collaborative work that grants workers relative autonomy in the labour process and facilitates self-expression and opportunities to engage in total human activity. Cultural workers feel great attachment to the products they create, particularly when these products carry a worker's name, such as a novel or a film. It is difficult to reconcile Marx's interpretation of work as an alien power, "not voluntary, but coerced" (Marx [1844] 1978a, 74), with conceptions of cultural work as highly desirable and glamourous. ${ }^{2}$

In a position I review in greater detail below, critical theorists argue that that the specificities of cultural commodities require that workers at the idea-creation stage of production be granted relative autonomy in the labour process (Ryan 1992; Banks 2010). Relative autonomy enables some cultural workers to enjoy more time, autonomy, and resources than other workers are granted, which diminishes experiences of alienation (Hesmondhalgh 2007, 70). Although relative autonomy is always tenuous and negotiated, this arrangement has led to arguments that cultural work should be understood as a potential site of "good work" or as work that grants opportunities to produce "'radical' autonomous critique" even within the confines of capitalism (Hesmondhalgh and Baker 2011; Banks 2010, 252). Contemporary conditions of cultural production, however, are undermining relative autonomy. Cultural workers are experiencing declining material conditions and intensifying precarity, defined as "intermittent employment and radical uncertainty about the future" or "financial and existential insecurity" (Ross 2009, 4; Brophy and de Peuter 2007, 180). Indeed, precarity has become a central feature of cultural work. Although a variety of interdisciplinary approaches are necessary for thinking through the complexities of cultural work - which can be simultaneously precarious and satisfying, risky and rewarding - Marx's understanding of the inner logic of work provides a foundational understanding of the structural forces giving form to cultural work.

Marx's foundational concepts ${ }^{3}$ bring useful insights to bear on investigations of the transformations in work and workers' lives. In what follows, I argue that a dynamic Marxist political economy approach can account for the processes, practices, and structures that have resulted in the increasing precarization of cultural work. In particular, exploitation remains the key process driving transformations in the cultural industries and can account for the ways cultural workers' relative autonomy is being undermined. To demonstrate this, I draw on examples from an ongoing case study of freelance writers, a growing segment of the Canadian media labour force ${ }^{4}$. As freelancers are increasingly learning, stepping out of an employment relationship (or being denied one, as is rapidly becoming the norm) does not mean an escape from exploitation or labour-capital antagonisms. Whereas capital has historically increased surplus value by extending the working day and intensifying production (Marx [1867] 1990, 645), corporations that rely on freelance labour have developed alternate methods of extracting surplus value from workers. For writers, these methods include an increase in unpaid labour time and the aggressive pursuit of copyrights.

A Marxist political economy that is process-oriented, historical, and attentive to workers' agency and desires for autonomy provides insights into current conditions. Studies of cultural work can benefit from a materialist approach that understands work in these industries in relation to dynamics of capitalism and an approach that positions cultural work as a site of struggle. Many accept precarious conditions as the new reality that media workers in volatile industries must consent and adapt to, including industry, the state, training institutes, scholars, and workers themselves (McRobbie 2002; Deuze 2007; Hesmondhalgh 2007, 207). A Marxist approach disrupts this mindset to uncover dynamic processes that reveal a deeper understanding of the nature of cultural work and how it has evolved. In what follows, I outline a Marxist approach to cultural work and discuss the challenges and possibilities for considering cultural work through the lens of labour process theory. I then introduce a case study of freelance writers and examine dynamics of exploitation of

\footnotetext{
${ }^{2}$ In Capital, Marx describes alienation not as a subjective experience, but in an objective sense, as a way of being under a mode of production organized around private property and waged labour. For Marx, workers are alienated because they do not own the means of production and must to sell their labour power to survive.

${ }^{3}$ Other aspects of Marx's thought are useful for understanding the character of cultural labour, particularly his writing in The Grundrisse, which has been taken up by autonomist Marxists to interrogate the way contemporary capital incorporates general intellect, and workers' affect and personalities into the accumulation process on an unprecedented scale. In this paper, however, I want to focus on Marx's "old" concepts (Huws 2003, 135), which receive less attention in communication and cultural studies.

${ }^{4}$ This study is based on a qualitative survey of 200 freelance writers across Canada and interviews with representatives of freelance writer organizations. Unless otherwise cited, all quotes in this paper were provided by writers who participated anonymously in my survey.
} 
unpaid labour time and copyright. I conclude with a discussion of how positioning cultural work as a site of struggle reveals possibilities for transformation.

\section{Back to Marx: A Political Economy of Cultural Work}

A Marxist political economy of cultural work is concerned with the dynamics of the labour-capital relation, tensions and contradictions that structure this relationship, struggles over control and exploitation, and with questions of power and resistance. This approach flows from an understanding that these practices and processes are situated within a particular historical context: capitalist commodity production, under which those who do not own the means of production must sell their labour power to earn a living, thus engaging in a consensual relationship of exploitation of surplus value. Countering the rejection of Marxism as reductive, David Harvey $(1996,49)$ argues that Marx must be understood as a dialectical thinker concerned with "processes, flows, fluxes, and relations" rather than an analyst of structures and things. Marx uncovers the processes that constitute and sustain capitalism (ibid., 50) and accounts for "unfolding and dynamic relations between elements within a capitalist system" (Harvey 2010, 12). His concepts capture the dynamic relations and contradictions propelling the change and instability inherent to the process of capital accumulation (Harvey 1996, 54).

A Marxist political economic analysis of cultural work speaks to the historical developments of cultural industries, which did not emerge fully formed but rather are the result of contestation about how to produce culture and how to organize work. A historical, process-oriented perspective reveals how taken-for-granted characteristics of cultural work - its volatile, project-based, precarious nature - are often the result of transformations in media and cultural industries that have occurred alongside shifting dynamics of capitalism. Most recently, this shift has been a transformation from Fordist mass production to a flexible accumulation regime ${ }^{5}$ organized around lean production, information communication technologies, and deregulated and flexible labour markets (Moody 1997; Albo 2010). In this context, cultural industries have undergone significant change, which shapes workers' experiences (ILO 2000; Gough-Yates 2003; Hesmondhalgh 2007; Deuze and Fortunati 2011). For example, it is widely accepted that workers in cultural industries have "boundaryless" or "portfolio careers", which means they perform work for multiple engagers on a project basis, often simultaneously (Leadbeater and Oakley 2005; Hartley 2005). However, the portfolio nature of careers is more often described as an inherent trait of cultural workers themselves and less often as a coping strategy to deal with work made intermittent and precarious - a decidedly less glamorous view, but one that links work arrangements to broader political economic dynamics. The role of capitalism in shaping cultural work and the resulting power relations are obscured in many accounts of cultural work and directly situating cultural work in capitalist production relations reaffirms a materialist approach to the study of media, culture, and communication.

Marx is often overlooked in studies of cultural work because he did not attend to workers' subjectivity, and subjectivity is a key component of cultural work, which "is first and foremost about communicating meaning and very often also about identification and pleasure" (McGuigan 2010, 326). Indeed, subjectivity is a crucial component of all types of work, especially now that contemporary capitalism increasingly requires the incorporation of workers' subjectivities into production (Dyer-Witheford and de Peuter 2009, 4). Subjectivity is important for considering the limits of capital's ability to contain cultural workers' resistance and for considering how and why cultural workers choose to collectively organize in particular ways (de Peuter 2011; N. Cohen 2011). However, as Harvey $(2006,113)$ argues, it is difficult to understand current experiences of cultural work primarily through workers' subjective experiences of labour. It is first critical to understand the objective conditions of that labour, or, "what it is that workers are being forced to cope with and to defend against; to come to terms with the manifest forces that impinge upon them at every turn" (ibid., emphasis in original).

This approach stems from Marx's ([1852] 1978b, 595) assertion that people "make their own history, but they do not make it as they please; they do not make it under circumstances of their own choosing, but under circumstances existing already, given and transmitted from the past". Of course cultural work holds potential to be fulfilling and provide a sense of creative autonomy, if

\footnotetext{
${ }^{5}$ Harvey $(1990,147)$ uses the term flexible accumulation to describe the regime of accumulation that has followed the gradual shift from Fordism in the early 1970s, characterized by flexible labour markets, labour processes, and consumption patterns, as well as the emergence of new technologies and financial services. Vosko $(2010,89)$ argues that this concept is preferable to terms such as post-Fordism because it emphasizes "continuity through change," or the "continuation of aspects of the system of mass production associated with Fordism alongside the expansion of new productive technologies and greater specialization" (Vosko 2000, 27).
} 
indicated just by the increase in numbers of cultural workers, the expansion of education and training programs, and fierce competition for work that is generally insecure and low paid, or not paid at all (Hill and Capriotti 2009; Perlin 2011; Lacey 2011). To understand why work is experienced in particular ways requires broadening the focus from individual experiences to consider cultural workers as part of a class of workers struggling over the terms of the commodification of their labour power. The Marxist approach positions workers as active subjects engaged in a dynamic process of production with contested power relations, not simply as "brutalized and exploited workers" (Conor 2010, 31).

To maintain a connection to the broader social totality and the conditions of labour under capitalism, Marxist political economy avoids setting cultural workers apart as wholly unique. Mike Wayne (2003), for example, draws out Marx's relational conception of the connections between all workers under capitalism, conceived through the lens of class as a social relationship. Wayne acknowledges the "wider social conditions of creative and intellectual labour as a collective relationship occupying a contradictory position between capital and the 'traditional' working class" (7). He draws on Erik Olin Wright's (1978) theorization of the class character of intellectuals - defined as "a category of people...whose activity is primarily that of elaborating and disseminating ideas" (192) - in advanced capitalist societies. Wright argues that because intellectual workers do not control the labour of others nor maintain "real control over much of their own labour process", these workers "typically occupy a contradictory class location between the working class and the petty bourgeoisie at the economic level and between the working class and the bourgeoisie at the ideological level" $(106,204)$. Cultural workers occupy a contradictory class location because they are integrated into capitalism yet differentiated from the working class by "cultural privileges, relative workplace independence and (usually) by remuneration levels", but they are not capitalists: their "status as labour reasserts itself whenever [these workers] are subject to similar processes of exploitation and proletarianization as the working class below them" (Wayne 2003, 23). As I will demonstrate, cultural workers' status as labour is reasserting itself at a rapid pace.

Although there are important differences between workers, these differences are not absolute. Rather, workers in various sectors and occupations can be understood as different parts of a social and economic class that must sell its labour power to survive (Wayne 2003; Smith and McKinlay 2009a). Whereas capital seeks to establish a hierarchy between mental and manual labour, Marx emphasized the process "by which capital develops a socially unified labour capacity in which particular roles represent only a limb of the total labourer", while all work under capitalism is submitted to generalized exploitation (Wayne 2003, 15). This understanding of cultural work retains a notion of labour-capital antagonisms and of class struggle, and so can account for transformations in media forms, technology, and business models. Capital's "immanent drive" to increase surplus value by cheapening the cost of labour (Marx [1867] 1990, 437) clashes with workers' desires to pursue meaningful work, to be paid decently for their labour power, and to be able to sustain themselves.

A Marxist conception of class avoids setting cultural workers apart as exceptional types of workers. It refuses the tendency to understand cultural workers' actions as motivated by artistic temperament, personality, and by an insatiable "desire to create", making links instead to the political economic context in which they work (Caves 2000, 3; Christopherson 2009, 74). The nature of the market economy, regulatory frameworks, state and employer policies, the organization of industries, wages, and access to union protection, for example, influence workers' actions and experiences. For a full understanding of cultural work, research should integrate an understanding of "enduring features" of cultural work, such as risk and uncertainty, with historical analysis of the political economic context structuring these dynamics (Christopherson 2009; Hesmondhalgh 2007; Miège 1989).

Key to this analysis is Marx's concept of exploitation, which occurs when one group (workers) produces a surplus that is controlled by another (capitalists) (Himmelwit 1983a, 157). Under capitalism, exploitation occurs through the extraction of surplus value, which Marx viewed as arising from the division of the working day into two parts: during the first part, the worker spends socially necessary labour time producing the equivalent of her wage; during the second, the worker spends surplus labour time producing profit for the capitalist (1983b, 474). It is this process of exploiting surplus value that drives capital accumulation and class conflict. As Susan Himmelwit (ibid.) writes: "the history of capitalist production can be seen as the history of struggle over attempts by capital to increase, and attempts by the working class to resist increases in, the rate of surplus value".

Exploitation is a dynamic concept. It links antagonism and resistance: those who exploit workers are also dependent on workers to realize surplus value, which gives workers power, an "inherent capacity to resist" (Wright 1997, 35). The process of exploitation includes worker agency, resistance, and a desire for autonomous forms of work. Autonomist Marxism, which theorizes capital 
as always confronting and reacting to workers' resistance, provides a framework for this approach (Cleaver 2000). Under this view, capitalist cultural production is not a top-down process of domination, but dynamic and constitutive, reacting to workers' agency and, often, militancy. However, as Marx demonstrates in Capital, "capitalism is characterized by fetishisms that obscure, for both capitalist and worker alike, the origin of surplus value in exploitation" (Harvey 2006, 113). The labourcapital relations in cultural work can be obscured for a variety of reasons, including the fact that choosing to pursue cultural work despite the risks can be empowering, that an ideology of enterprise increasingly underscores cultural work, and that cultural work is based on personal relationships that can mask economic relations (Lorey 2009; Neff, Wissinger and Zukin 2005; Ekinsmyth 2002). Relations of exploitation can be so obscured that it often seems as if cultural work is not really work at all, giving rise to a "labour of love" discourse that preempts discussions of power relations (Beck 2003,3). A return to Marx uncovers the antagonisms and social relations of capitalism that pervade cultural work. Traditionally, labour process theory has been at the core of Marxist studies of work. In the next section, I discuss the relevance of labour process theory for studying cultural work.

\section{Labour Process Theory and Cultural Work}

As a body of scholarship, labour process theory emerged from Harry Braverman's ([1974] 1998) critique of the organization of work under capitalism and its deleterious effects on workers' skills. Drawing on Marx, Braverman sought to understand the contradiction of modern work, which required increasing training and skill yet produced greater dissatisfaction. Braverman describes how the labour process is subsumed under and shaped by processes of capital accumulation: work is continually brought under capitalists' control in order to extract value from workers, and the labour process is rationalized, first in the factory, then in the office, transforming the labour process from an activity that creates something useful into a process explicitly designed to expand capital. Structural dynamics of competition and accumulation push capitalists to constantly revolutionize the process of production to increase productivity and lower labour costs. This impels capitalists to obtain control over the labour process. As Marx ([1867] 1990, 436-7) writes, "capital... has an immanent drive, and a constant tendency, towards increasing the productivity of labour, in order to cheapen commodities and, by cheapening commodities, to cheapen the worker himself". This process is carried out by applying new technologies and principles of scientific management to the labour process, dividing work into its constituent parts, deskilling workers, separating conception from execution, and bringing work under management's control (Braverman [1974] 1998, 49, 118).

Braverman argued that capitalism tends to reduce the majority of workers to a homogeneous group of interchangeable labourers who require little specialized training. In some cases, his vision of degraded work has been carried into the digital age. Consider, for example, the growing market for digital piecework, where mental labour such as research, translation, and design are broken into small tasks and farmed out to people working remotely for alarmingly low pay on websites like Mechanical Turk, ODesk, and Microtask. Yet labour process theory has some limits in the context of cultural work, particularly the creative aspects of cultural work. For one, labour process theory has been predominantly workplace focused and concerned with workers in employment relationships, and cultural work is increasingly situated outside of these structures. In addition, cultural workers seem to need no coercion to fully invest themselves in their work or to work long hours for low pay (Ursell 2000; McRobbie 2002). Finally, the argument that cultural workers have been granted relative autonomy at the point of production seems to challenge the relevance of labour process theory.

Michael Chanan (1976; 1983) and Bill Ryan (1992) trace a lineage from art and artistic practice to labour in the commercialized cultural industries, drawing on Marx to outline a conception of aesthetic labour - forms of labour in which, unlike in other commodity production, it is difficult to completely separate the author from her work. As artistic practice is brought under the logic of capitalist commodity production, the "art-capital contradiction" emerges, defined as a source of conflict inherent to the transformation of culture into capital (Ryan 1992, 34). Historically, for cultural commodities to have use values, these commodities must retain a trace of the person who created them, especially in instances of "person-specific" or personalized labour, where the creator's name is attached to the work (Smith and McKinlay 2009a, 12; Ryan 1992, 136). As Ryan (45) writes, "every book must have an author, every score a composer, every film a writer, director [...] unlike cans of peaches, lines of cars [...] where the direct producers of these commodities are entirely unknown to their purchasers. Artists must be engaged as named, concrete labour". Even cultural producers who are not "stars" - that small group for whom name recognition fetches high remuneration (Hesmondhalgh 2007, 199) - are valued because "of the identifiable, expressive abilities at- 
tributable to and inseparable from each and each alone" (Ryan 1992, 44).

The requirement for concrete labour limits the extent to which the idea creation process in cultural work can be broken down and divided into constituent tasks, and so cultural industries have tended to grant relative autonomy to workers at the point of creation (idea and symbol generation), while tightening control over reproduction, distribution, and circulation of cultural commodities (Chanan 1979; Miège 1989; Ryan 1992; Hesmondhalgh 2007). As Chanan (1983, 318) writes, "the content of cultural forms cannot, in the last instance, be mechanized". Workers who create originating texts cannot be replaced with machines or with other people without altering the text ${ }^{6}$. This complicates the production process for capitalists. Usually, capital's compulsion to lower the costs of production has required that concrete labour - specific skills or tasks performed by a particular worker - be reduced to average levels so that it does not matter who performs the work. Ideally, individual workers are transformed into abstract labour: interchangeable inputs for production, their particular contributions congealed in and disguised by the commodity form. Capital's compulsion is to separate conception from execution and to reduce workers' specialized knowledge and heterogeneous skills to simple labour (Braverman [1974] 1998; Harvey 2006, 57).

Recognition of the structural tendency to grant cultural workers relative autonomy at the point of production has served to eject labour process analysis from studies of cultural work (notable exceptions include Murphy 1991; Im 1997; Ursell 2000; Smith and McKinlay 2009a). For if it is true that cultural workers have control over the process and products of their work, then it seems labour process theory and its Marxist heritage are no longer relevant. Many cultural workers are so selfmotivated that they "set themselves" to work, working excessively long hours for little pay, embracing uncertainty and risk in order to pursue careers in culture (McRobbie 2002, 101; Ursell 2000). From this view, managers are not required to motivate cultural workers or increase productivity and cultural workers are considered to self-exploit. But identifying self-exploitation, while key to uncovering the myriad ways power operates, can mask true relations of exploitation, almost letting capital off the hook.

Sheila Cohen (1987) argues that labour process theory cannot be so easily sidestepped. She argues that the post-Braverman labour process debate was too focused on questions of control, neglecting the process of exploitation that is at the core of the capitalist labour process. It is not control that "constitutes the principal dynamic at work in the capitalist labour process", but rather exploitation, ownership over the means of production, and class (ibid., 35, 66). Cohen recasts the focus of labour process theory on valorization and exploitation, which is the motor of capitalist accumulation and production, fundamentally structured around the extraction of surplus value from workers. The labour process is political not because of an "ongoing power struggle over managerial domination", but because it is "the site of the central dynamic of [...] exploitation and the generation of surplus value" (39). This means that control over production can be surrendered if it is not an impediment to exploitation. Indeed work is constantly reorganized to suit capitalism's overall objective of valorization (Braverman [1974] 1998), and ceding control over the labour process to certain workers is exactly in line with some needs of accumulation. This ranges from empowerment strategies on the factory floor (Moody 1997) to "fun" environments in the permissive offices of new media firms designed to capture workers' creative and emotional potential; their "freest thoughts and impulses" harnessed for productivity (Ross 2003, 19; Dyer-Witheford and de Peuter 2009). In some ways, this loosening of control is a descendent of the age-old strategy of lengthening the working day. Pondering the playful offices of amenity-packed new media firms, Andrew Ross $(2001,78)$ wonders, "who would ever want to go home?".

More overt attempts to rationalize production are evident in forms of cultural work that have previously seemed impervious to organizing the author out of production. Consider Alloy Entertainment, a company that generates book projects for publishers, pumping out thirty books per year targeted to teen girls. What is unusual about this "book factory" (Semuels 2008) is not the formulaic plots and generic tropes Alloy relies on for mass-market appeal, but the way labour is organized in the production of each book: ideas are brainstormed at a meeting, an editor composes a story, and a writer is hired on spec to draft a chapter. The writer works closely with editors to develop the plot and produce more chapters. Alloy pitches the chapters, a book synopsis, and a cover image to publishers, retaining all rights to the intellectual property. Often, company-owned pseudonyms are used instead of real writers' names, and some names represent a team of ghostwriters (Mead

\footnotetext{
${ }^{6}$ This argument is perhaps best demonstrated by the embodied nature of performing arts work. As William Baumol and William Bowen $(1966,164)$ write, changes in the training or specificities of a performer "affects the nature of the service he supplies." Unlike manufacturing workers, "performers are not intermediaries between raw material and the completed commodity - their activities are themselves the consumers' goods" and therefore the specific worker cannot be separated from the work of performing.
} 
2009). Perhaps an extreme case of rationalizing literary production, yet Alloy offers an example of how capital finds ways around the need to grant creative workers relative autonomy if and when it is required for profitable production. Under Alloy's model, it does not matter who writes a particular book. Authors, formerly assured the privilege of being named labour, are interchangeable and often not credited for their work.

Labour process analysis that draws on dynamic concepts from Marx remains a relevant method for researching cultural work, providing a theoretical foundation for an investigation of cultural work in its various and specific forms. Labour process theory centres on processes of capital accumulation and opens a critical line of inquiry: if the continuity of capitalist production has thoroughly penetrated the cultural industries and if exploitation is fundamental to the capitalist labour process, how does this dynamic manifest in cultural work? If cultural workers have been granted relative autonomy at the point of idea creation, how then does capital respond? In most instances, firms tighten control over workers who do not require relative autonomy in production, creating divisions in status, job quality, and material conditions between workers in cultural industries. Increasingly, and as technologies change, however, cultural workers' relative autonomy is being further encroached upon. This is especially the case for writers who pursue freelance work in order to claim some autonomy over their craft. A case study of freelancers reveals these tensions.

\section{Case Study: Freelance Writers}

On the surface, freelance writers seem removed from the capitalist labour process. Legally classified as independent contractors, freelancers work for multiple clients to produce one-off pieces or are hired for short-term projects. They write for magazines, newspapers, books, and produce content for corporations, governments, and $\mathrm{NGOs}^{7}$. The labour-capital relations that underscore freelance cultural production are often obscured: because freelancers are not engaged in an employment relationship and are not paid a salary, it appears that they sell simply a finished piece of work, or "labour already objectified in the product" (Marx [1867] 1990, 692), not the labour time required to produce that piece. However, Marx argues that piece wages are a form of time wages and that the existence of this form of payment "in no way alters [its] essential nature", which is "the general relation between capital and wage-labour" $(693,696)$. Freelance cultural work has relations of exploitation at its core.

Historically, piecework has been a method of lowering wages and lengthening the working day (698). For cultural workers, however, freelancing provides an escape from the employment relationship, a way to gain some control over where and when they work, what they work on, with whom, and how work is performed. But despite writing for profitable media industries (Winseck 2010), Canadian freelance writers' incomes have been stagnant for over three decades, averaging $\$ 24,000$ before tax (PWAC 2006). In a survey I conducted of 200 freelance writers across Canada, 45 percent of respondents reported earning under $\$ 20,000$ (before tax) from freelance writing in 2009 , and 71 percent of these writers say that freelance writing is their main job.

While freelancing is presented as the ultimate freedom for workers (Pink 2001), it is also an ideal arrangement for capital. Freed from the burden of employment, relieved of the costs of training, overhead, benefits, and paying for unproductive time, firms can hire someone for a short-term project or purchase only completed works: an article, a piece of research, a design. The risks and costs of production are downloaded onto workers who, motivated by the relentless search for work and increasing competition, strive to produce their best works, providing capital ample choice from a pool of skilled workers bargaining down the costs of their labour power. This arrangement allows for relative autonomy in creative production yet impels firms to develop alternate methods of extracting surplus value. For publishers, exploitation is made easier by the casualization of media work, which has increased competition for work, made workers insecure, and pressured wages down.

Marx's ([1867] 1990, 697) observations on piece wages point to the contradictions of freelance work:

the wider scope that piece-wages give to individuality tends to develop both that individuality, and with it the worker's sense of liberty, independence and self-control, and also the competition of

\footnotetext{
${ }^{7}$ The freelancers I study are primarily freelance journalists who write for newspapers, magazines, and online journalistic outlets. However, because it is so difficult to earn a living solely from freelance journalism, many freelancers have expanded the types of work they perform to include a range of industries and formats. For this reason, I use the broader term freelance writer.

${ }^{8}$ The Professional Writers Association of Canada surveyed 858 freelance writers, most of whom are full-time writers, meaning that writing is their sole source of income (PWAC 2006).
} 
workers with each other. The piece-wage therefore has a tendency, while raising the wages of individuals above the average, to lower this average itself.

This demonstrates the dialectical nature of the labour-capital relation: workers constantly seek to resist exploitation and capital constantly reorganizes to address workers' resistance. As Harvey $(2006,116)$ writes, "if the value productivity of labour can be better secured by some reasonable level of worker autonomy, then so be it. Capital is, presumably, indifferent to how the value productivity of labour is preserved and enhanced". Increasingly, capital secures the value productivity of labour through exploiting freelancers' unpaid labour time and copyrights to their works. I examine each example in turn.

\section{Labour Casualization and Exploitation of Unpaid Labour Time}

Working as a freelancer has traditionally provided journalists a way out of the strictures of an employment relationship and the limitations of routinized news production to pursue more creative, experimental, or interesting writing. However, what was once a strategy available to a small segment of journalists who could leverage a monopoly over their skills to build freelance careers has become a core business model as the media workforce is casualized. As companies download more of the risk and costs of doing business onto workers, the autonomy freelancers have enjoyed, even in the face of low pay, is being undermined.

By now the shift to precarious forms of employment is well documented (Vosko 2006; Standing 2011). In line with the neoliberal transformation of capitalist economies and the resulting restructuring of work and employment dating from the 1970s (Vosko 2000; Albo 2010), cultural industries have moved from production based on full-time, steady employment to more precarious forms: part-time, temporary, casual, contract, and freelance (Murdock 2003; Nies and Pedersini 2003; Walters, Warren and Dobbie 2006; Smith and McKinlay 2009b). Typically, this work has low wages, no benefits, little job and social security, limited access to union protections, and long working hours. Cultural work has been casualized, transformed from "internal and regulated labour markets" to networks of individuals providing specialized services on an as-needed basis (Smith and McKinlay 2009b, 29; Hill and Capriotti 2009). These changes are linked to firm strategies such as concentration, convergence, and outsourcing, the erosion of union power, and the spread and acceptance of precarious forms of employment. They are also made possible by a restructured global division of labour that harnesses information and communication technologies to establish chains of flexible accumulation spanning the globe, chains that begin from the outsourcing of components of the production process to the low-waged regions of the world and link to the outsourced work now performed in the homes of knowledge, information, and cultural workers in western capitalist states (Huws 2007). Although cultural industries have a history of non-standard forms of work, ${ }^{9}$ accepting freelance, contract, or temporary employment is no longer a choice as firms shed their workforces, flooding the labour market with freelancers (Nies and Pedersini 2003; PWAC 2006; Walters, Warren and Dobbbie 2006; McKercher 2009). Rather than continuously employing people, cultural industries maintain loose affiliations with networks of cultural producers constantly developing ideas from which firms can pick and choose.

This "reserve army" of cultural workers (Murdock 2003, 22) absorbs cultural firms' financial risk, which is offloaded onto individuals. Because the creative stage of production cannot be completely rationalized, companies trade relative autonomy for the ability to extract higher value through contract and freelance status, protecting capital from risk, lowering labour costs, and intensifying competition for work (Ryan 1992, 48; Hesmondhalgh 2007; Smith and McKinlay 2009b, 40). Projectbased work, short-term contracts, and freelance arrangements demonstrate some of the underlying contradictions of cultural work: these relationships grant workers the relative autonomy and flexibility required to develop creative works, but absolve firms of paying a salary and the benefits associated with secure employment. The benefits of autonomy are often undermined by precarity. This arrangement, despite having roots in political economic dynamics, has perpetuated the notion that to be a cultural worker one must accept and adapt to intermittent employment, low wages, and precarity, drawing out the romanticized notion of suffering for one's art into industrialized, highly capitalized cultural industries (Menger 1999; Ross 2000).

As pieceworkers, freelance writers are usually paid per word or per article (or, as the unfortunate joke goes, "perhaps") ${ }^{10}$. By purchasing finished stories from freelancers; publishers do not pay for time spent developing and researching ideas, pitching stories, conducting interviews, or for time

\footnotetext{
${ }^{9}$ Indeed, cultural industries are credited with serving as a model of flexible, project-based, work for other industries (Ross 2009, 18-19; McRobbie 2004).

${ }^{10}$ Kingston and Cole 1986. For corporate and non-journalism contracts, freelancers are usually paid per hour.
} 
spent editing and rewriting. The arbitrary per-word form of payment, popular among magazines and newspapers, obscures a large portion of the labour that goes into the writing of those words. As one freelance writer explains: "The pay often does not reflect the work you put into a piece. You are expected to come up with ideas, research and pitch without pay, yet are not adequately compensated when your story ideas are accepted". Added to this are the crucial tasks of sourcing and securing work, self-promotion, training and skills development, invoicing and chasing payments, and the various other tasks involved in maintaining a freelance career. As I discuss below, once an article is written, the costs of reproduction for companies is minimal, yet writers are often not paid for multiple use of their works in various formats, or "the labour power that is still latent within the article" (D'Agostino 2010, 238).

As Marx explained, unpaid labour that contributes to the generation of surplus value for capitalists is exploited labour ${ }^{11}$. And exploitation is spreading throughout the cultural industries, thanks to the casualization of the labour force, which leaves a growing number of workers stitching work together to earn a living, paid for far less than the time required for production of their works. This glut of freelance and un- and under-employed workers represents huge value for companies, as competition for work pressures wages downwards. New forms of temporal exploitation are made possible by processes of spatialization, or extending the capacities for value extraction into new spaces - in this case, workers' homes (Mosco 2009). Media corporations capitalize on this arrangement, building business models on access to flexible, cheap, or free labour they need not employ. For example, firms are replacing paid workers with unpaid internships; writers are increasingly paid in "exposure" on profitable websites such as The Huffington Post, and skilled employees are laid off because major news networks such as CNN can increasingly rely on volunteersubmitted content, or exploit "citizen" journalism through "crowdsourcing" (Perlin 2011; Guthrie 2011; Kperogi 2011). These strategies are complemented by the intensifying exploitation of copyrights.

\section{Copyright as Exploitation}

Freelance writers' livelihoods in a digital age are built on the shaky foundations of copyright protection, which are being eroded by corporations' tightening grip on intellectual property rights. Unlike employees, who in exchange for salaries give up ownership of works they produce to employers (D'Agostino 2010,4), freelance writers in Canada are legally classified as independent contractors and therefore own copyrights to the articles they write. Publishers are granted a limited licence to publish articles in designated publications for specified periods of time (Canada 1985, s.13; D'Agostino 2004, 6). Traditionally, this has been a benefit of working freelance, enabling writers to re-sell articles and in some way compensating for low rates of pay (Lorinc 2005, 37; PWAC 2006, 41). However, traditional practices are being undermined by uses of new technologies and aggressive publishing strategies.

The growth and consolidation of media and entertainment firms over the past few decades has been enabled by technological development, especially digital communications and digitization, a process that provides a universal language for media content and has led to convergence across media platforms, allowing corporations to deepen the exploitation of labour (Mosco 2003). Digitization enables quick transmission of information and simplifies duplication, especially online, which means publishers can repackage information for publication in multiple formats.

Most periodical and newspaper publishers in Canada are part of large media chains that control a range of integrated media properties and are hungry for content that can be re-purposed for various platforms. Digitization helped corporations realize their ambitions of concentration and convergence, aided by and fuelling the push to obtain copyrights (D'Agostino 2010,20). These rapid shifts in corporate media organization have directly affected freelance writers' earnings, initially by shrinking the number of markets in which writers can re-sell work (PWAC 2006, 35).

These practices have grown more pervasive as they have moved online. For example, in Fall 2010, Rogers Media, a division of the massive media conglomerate Rogers Communications, began syndicating articles written for its magazines by freelancers to other websites without alerting writers, let alone paying them for extra use (Scott 2010; Story Board 2010). Unbeknownst to writers, executives began syndication as an initiative of Rogers Digital Media, which promotes access to its content to advertisers. Rogers Digital Media claimed the syndication was covered under the

\footnotetext{
${ }^{11}$ Feminist activists and political economists have long been arguing that unpaid labour time is valuable for capitalism, particularly the unpaid labour performed by women in the home. See, for example Waring 1999 and Dalla Costa and James 1972. McKercher (2009) makes important links between women's unpaid household labour and the precarious work of freelance writing.
} 
"promotions" clause in Rogers' new standard contract all writers must sign, which states that Rogers can "publish the Work and/or an edited version thereof in any promotion of the publication and/or its brand in all forms of media" (ibid.). Writers' organizations, however, claim that this is a broad interpretation of the contract: "most contributors would not read 'promotion' as syndication on [websites] many months after their story first appears in a Rogers publication," argued freelance writer agent Derek Finkle (Scott 2010).

This example demonstrates publishers' growing desire to own outright the rights to writers' works, which are cheap to "digitally recycl[e]" into new profit (D'Agostino 2010, 239). This strategy aligns with Marx's ([1867] 1990, 325) explanation of surplus value: after a worker earns enough to reproduce her labour power, the capitalist owns the rest of the value she produces, which "for the capitalist has all the charms of something created out of nothing". Most large publishers now present writers with "streamlined" contracts that claim all copyrights for writers' works at once (D'Agostino 2005, 166). Contracts can demand, for example, "all rights, in perpetuity, throughout the universe" in any form, including rights for media formats yet to be invented. These contracts are generally non-negotiable and do not offer extra payment for extra rights (PWAC 2006, 35). Depending on the company and its media holdings, rights demanded can include translations, digitizing, adaptations and performances, reprints, relicensing, promotions, and storage of articles in electronic databases.

Current contracting regimes have effectively expanded possibilities for exploitation of surplus value indefinitely (D'Agostino 2010, 241). Economists view copyright primarily as providing economic incentive for creators to produce intellectual and artistic works (Bettig 1996, 7; Towse 2003). However, under the capitalist mode of cultural production, copyright's primary function is to guarantee its owner exclusive right to exploit the work and to extract surplus value from workers who have been granted relative autonomy at the point of production. With workers providing services on a one-off basis, companies need not be concerned with how works are created, as the real value for corporations lies in the continued exploitation of completed works. Notes one freelance writer, "No one cares where I am, just as long as I get the work done". What matters to firms is not the time spent on a project or the pace of work - control over the labour process - but ownership over the final product, which can be re-published, re-licensed, and re-purposed, generating surplus value from the works themselves and lowering labour costs.

Capitalism developed by generating technological methods of extracting knowledge from workers to control production and increase efficiency and exploitation (Braverman [1974] 1998), and continues this trajectory by claiming ownership of the information workers produce (May 2002, 318). This is a crucial, under-examined link between cultural work and capital, obscured either by a focus solely on the autonomy of cultural workers or by a failure to acknowledge that it is labour that creates the texts, images, ideas, and symbols that are transformed into private property (Rossiter 2006, 145).

Copyright has become a high-stakes site of struggle in Canada and beyond. Freelance journalists in North America have won class action lawsuits against publishers for using works without acknowledgement or extra payment (D'Agostino 2010). Film and television writers struck for three months in 2007-2008 to win a greater share of residual money from DVD sales and revenues from digital downloads (Klowden and Chatterjee 2008). Freelance photographers effectively delayed the launch of People magazine's iPad app over its licensing agreement, as photographers demanded payment for use of their photos beyond the pages of the magazine (Wallenstein 2010). Book producers such as Alloy Entertainment and Full Fathom Five ${ }^{12}$ are transforming copyright relations between writers and publishers by hiring authors to write pre-fabricated books, often under a pseudonyms, and retaining all rights to their works, generating licensing deals for film and television while contractually barring writers from claiming authorship (Mozes 2010). These struggles will become more charged as we move deeper into the digital age.

\footnotetext{
${ }^{12}$ Frey, a controversial writer, launched Full Fathom Five to tap into the commercial young adult fiction market. Frey hires newly minted (and indebted) MFA graduates to write novels for $\$ 250$ (some writers earn an additional $\$ 250$ upon completion of the book). The writer earns a percentage of all revenue the book generates (30 percent if the idea came from Frey, 40 percent if the idea was the writer's), including revenue from TV, film, and merchandise licensing. The writer does not own copyright to the book yet is responsible for any potential legal action. Full Fathom Five has the right to decide to use the author's name or a pseudonym, even if the writer is no longer involved in the project. The writer has no say in the use of his or her image in publicity photos or biographies and must sign a confidentiality agreement, risking a $\$ 50,000$ penalty for "admit[ing] to working with Full Fathom Five without permission." The terms of copyright on Frey's projects are nonnegotiable (Mozes 2010).
} 


\section{Conclusion: Cultural Work as a Site of Struggle}

A Marxist political economy approach to cultural work identifies the links between precarious working conditions and broader transformations underway in the cultural industries while also recognizing workers as agents who resist, struggle over, and negotiate their labour conditions. Without this powerful tool of analysis, based on Marx's foundational understanding of the labour process under capitalism, the manifestations of capitalist social relations in old and new forms can be obscured, especially as labour is casualized and digital technologies are used to transform production. As Marx argued, "capitalism is unique in hiding its method of exploitation behind the process of exchange" (Himmelwit 1983a, 158). Key to understanding the full experience of cultural work is discovering how exploitation shapes work and workers' lives.

In the case of freelance writers, exploitation is at the core of the casualization of work and the aggressive pursuit of copyrights. For freelancers, control over the labour process is traded for increased flexibility for employers and a greater extraction of surplus value from writers who are working harder for longer hours and earning lower wages (PWAC 2006). Although the market has long played a role in influencing the type of material writers could sell (Mills 1956; Kingston and Cole 1986), this pressure has intensified as publishers seek "content" that can be syndicated for use across multiple platforms. These new publishing practices limit the possibilities for writers to produce certain kinds of work, including longer pieces that require research, investigative journalism, and creative or challenging works that take time to produce. These limitations are reflected in Canadian freelance writers' experiences. Just over half of the writers I surveyed would most like to write long-form narrative features, creative non-fiction, essays, and investigative journalism. However, few find opportunities to pursue this type of work and to be compensated adequately for it. Other reports reveal a discrepancy between the type of writing freelancers most want to pursue (periodicals, books, and American magazines, which pay more) and the type of writing most do: writing for corporate clients and shorter magazine pieces that are faster to produce (PWAC 2006). As one writer says, "I've built my career on the 'service' journalism industry. It's paid my bills and helped establish my reputation and skills, but I would like to do more meaningful, issues-related writing. I do some, but there are probably three or four bill-payers for every piece I'm truly proud of". Increasingly, freelancers view their journalistic work, which motivated them to become freelancers in the first place, as a luxury to indulge in when time and money permit. These experiences trouble the concept of relative autonomy.

Because antagonism lies at the core of Marx's concept of exploitation and because capitalist production is "inherently, structurally a site of contestation" (Wayne 2003, 13), it is useful to conceive of cultural work as a site of struggle (see also Artz 2006). This conception is acknowledged in some studies of cultural work, where struggle manifests as tension between "artistic desires for creative autonomy" and the requirements of profit-oriented cultural production (Banks 2007, 6; Ryan 1992). A broader conception, however, views this struggle as labour-focused, as contestation over the terms of commodification and exploitation of labour power. Autonomist Marxist theorizing is useful here, as this approach begins from the notion that workers actively resist capitalist exploitation and enclosure, and that capital reacts to worker resistance, which always has the potential to escape capital's control. This cycle, in turn, generates new strategies and tactics of struggle among workers that threatens capitalism anew (Cleaver 2000; Brophy and de Peuter 2007, 178). As capital extends relations of exploitation, workers seek meaningful and autonomous forms of work. Autonomists view the move toward flexible work as partly motivated by workers themselves. For example, in his schema of the "precarious labour personas" found along a continuum of precarity in contemporary capitalism, Greig de Peuter $(2011,419,420)$ argues that "the autonomous worker" typified in freelance cultural workers - is subject to flexibility "instituted from above" but also desires this type of labour arrangement (see also Ross 2009; Vosko 2010; Hesmondhalgh and Baker 2011). As de Peuter $(2011,420)$ writes, "the autonomous worker is immanent to a genealogy in which the pursuit of flexible work in immaterial production is a decision taken in an act of selfdetermination and as a conscious rejection of standard work."

It is useful to consider freelance writers in this way. As journalism developed into a mass industry in the late nineteenth century, journalists were proletarianized, or brought under a system of wage labour, which standardized the labour of reporting (Smythe 1980). The introduction of formulaic news writing geared toward a mass audience challenged writers' independence and degraded the craft of writing (Carey 1969). Even as journalists gained professional status through unionization, many grew frustrated with anonymity, wage dependency, and routine conditions of work (Smythe 1980). Freelancing offered escape from reporters' descent into "a white collar proletariat" (Kaul 1986, 47) and the newsroom grind. Although the decision to work freelance is no longer a choice for most, many freelancers retain this spirit, seeking autonomy, the ability to pursue interest- 
ing and creative work, flexibility, and control over the terms of commodification of their labour power. Freelancing can also represent a more politicized conception of work and how it should be organized, hinting at a radical conception of a "refusal of work" and escape from the wage relation (Weeks 2011). As Andrew Beck $(2003,4)$ notes, freelance cultural work can be viewed simultaneously as "labour at the margins" and as "a last space of resistance"13.

As media industries continue to contract out work, as states envision entrepreneurial, creative cities populated with self-employed workers, with the rise of co-working spaces to absorb officeless workers, and with no shortage of work to be done, it would seem that the time of the freelancer has arrived (Horowitz 2011). However, freelance wages are generally low, incomes are intermittent, and workers are experiencing intensified precarity. These conditions demonstrate that in response to worker resistance, capital adjusts its strategies to exploit those who have seemingly escaped the wage relation, a continuation of labour-capital antagonisms.

The struggle takes on new dimensions as workers begin collectively organizing to address and resist precarious conditions. Alongside established unions in the film and television industries, workers in sectors not often considered sites of labour, such as modelling, art, and writing, are identifying and challenging conditions of their exploitation. Cultural workers in a range of sectors are reaffirming their status as workers by embracing the term "precariat," whose roots lie in European social and protest movements (Prickett 2012; Standing 2011; de Peuter 2011). Canadian freelance writers, who have historically organized in professional associations, are turning to union models to collectively improve low wages and exploitative contracts (N. Cohen 2011). The USbased National Writers Union has launched a "Pay The Writer!" campaign to protest free labour online and to set a fair wage scale for online freelance journalists. Canadian Artists' Representation/le Front des artistes Canadiens (CARFAC), which represents visual artists in Canada, is demanding payment for artists when paintings are re-sold, as the labour power embedded in their work generates surplus value for sellers (CBC News 2011). Building on CARFAC's model, artists in New York City formed Working Artists in the Greater Economy (W.A.G.E.) to organize around the demand that artists be paid for their labour in gallery shows. Also in New York, The Model Alliance was formed to recognize modelling as work and to challenge the exploitative relations that underpin models' affective labour (de Peuter 2012). Key to these initiatives is that cultural workers are naming and addressing the precise conditions of their exploitation.

Emergent efforts by cultural workers to collectively organize are significant for those concerned with labour movement renewal. These initiatives are attempting to organize the unorganized, often through experimental formations that could serve as "test cases" for how to organize precarious workers in a flexible economy (de Peuter 2010). These initiatives are raising awareness of labour struggles and power relations in industries that are generally under the labour movement's radar, either by establishing alliances with trade unions or by organizing outside of union structures. Underpinning these efforts are not demands to return to standard forms of employment, but rather policy proposals and demands that can build worker power outside of any particular workplace; demands that aim to reclaim non-standard work as a viable option for autonomous, flexible, yet secure work (de Peuter 2011; Vosko 2010). It remains to be seen if these efforts can build solidarity with the labour movement and politicize cultural workers, or if organizations will reinforce the individualism and entrepreneurialism underscoring cultural work under neoliberalism (Abrahamian 2012; N. Cohen 2011). Yet these initiatives signify changes underway that could have implications for labour politics and the way culture is produced.

As the rise in cultural worker organizing demonstrates, it is crucial to identify the processes, practices, and social relations that undermine autonomy in cultural work so that they can be interrupted. The need to disrupt the feelings of inevitability and self-responsibility that still pervade many cultural workers' outlooks is urgent, and requires a critical political economy approach that understands material conditions as "always active, always unsettled, always subject to change" (Artz 2006, 45). After all, in some of Marx's most famous ([1888] 1978c) words, the point is not just to interpret the world, but to change it.

\section{References}

Abrahamian, Atossa Araxia. 2012. The 'l' in Union. Dissent. Accessed May 16, 2012. http://dissentmagazine.org/article/?article=4094.

Albo, Gregory. 2010. The "New Economy" and Capitalism Today. In Interrogating The New Economy: Restructuring Work in the 21st Century, edited by Norene J. Pupo and Mark P. Thomas, 3-20. Toronto: University of Toronto Press.

\footnotetext{
${ }^{13}$ Or, as the editors of The New Inquiry (2012) put it in their magazine's precarity-themed issue, "Most of us juggle twoand-a-half jobs, knowing the only thing worse would be a single stultifying career".
} 
Artz, Lee. 2006. On The Material and The Dialectic: Toward a Class Analysis of Communication. In Marxism and Communication Studies: The Point Is to Change It, edited by Lee Artz, Steve Macek, and Dana L. Cloud, 5-51. New York: Peter Lang.

Banks, Mark. 2007. The Politics of Cultural Work. London: Palgrave Macmillan.

Banks, Mark. 2010. Autonomy Guaranteed? Cultural Work and the 'Art-Commerce Relation'. Journal for Cultural Research 14 (3): 251-269.

Baumol, William J., and William G. Bowen. 1966. Performing Arts: The Economic Dilemma. New York: The Twentieth Century Fund.

Beck, Andrew. 2003. Introduction: Cultural Work, Cultural Workplace - Looking at the Cultural Industries. In Cultural Work: Understanding the Cultural Industries, edited by Andrew Beck, 1-6. London: Routledge.

Bettig, Ronald V. 1996. Copyrighting Culture: The Political Economy of Intellectual Property. Boulder, CO: Westview Press.

Braverman, Harry. (1974) 1998. Labor and Monopoly Capital: The Degradation of Work in the Twentieth Century. New York: Monthly Review Press.

Brophy, Enda, and Greig de Peuter. 2007. Immaterial Labor, Precarity and Recomposition. In Knowledge Workers in the Information Society, edited by Catherine McKercher and Vincent Mosco, 191-207. Lanham, MD: Lexington.

Canada. 1985. Copyright Act. Department of Justice. Accessed May 16, 2012. http://laws-lois.justice.gc.ca/eng/acts/C-42/

Carey, James W. 1963. The Communications Revolution and the Professional Communicator. In The Sociology of Mass Media Communications, edited by Paul Halmos, 23-38. Keele: University of Keele.

Caves, Richard E. 2000. Creative Industries: Contracts between Art and Commerce. Cambridge, MA: Harvard University Press.

CBC News. 2011. Visual Artists Vie for a Cut of Resale Profits. CBC News. November 28, 2011. http://www.cbc.ca/news/business/story/2011/11/28/art-resale-right-carfac-auction-gallery.html.

Chanan, Michael. 1976. Labour Power in the British Film Industry. London: British Film Institute.

Chanan, Michael. 1983. Labour Power and Aesthetic Labour in Film and Television in Britain. In Communication and Class Struggle: Liberation, Socialism, edited by Armand Mattelart and Seth Siegelaub, 317-332. New York: International General.

Christopherson, Susan. 2009. Working In The Creative Economy: Risk, Adaptation, and the Persistence of Exclusionary Networks. In Creative Labour: Working in the Creative Industries, edited by Alan McKinlay and Chris Smith, 72-90. London: Palgrave Macmillan.

Cleaver, Harry. 2000. Reading Capital Politically. Leeds and Edinburgh: Anti/Theses and AK Press.

Cohen, Nicole S. 2011. Negotiating Writers' Rights: Freelance Cultural Labour and the Challenge of Organizing. Just Labour: A Canadian Journal of Work and Society 17 \& 18: 119-138.

Cohen, Sheila. 1987. A Labour Process To Nowhere? New Left Review 165 (October): 34-50.

Conor, Bridget. 2010. 'Everybody's a Writer' Theorizing Screenwriting as Creative Labour. Journal of Screenwriting 1 (1): 27-43.

D'Agostino, Giuseppina. 2004. Should Freelancers Keep Their Copyrights in the Digital Era? Copyright \& New Media Law Newsletter 8 (4): 6-8.

D'Agostino, Guiseppina. 2005. Freelance Authors For Free: Globalisation of Publishing, Convergence of Copyright Contracts and Divergence of Judicial Reasoning. In New Directions in Copyright Law, edited by Fiona Macmillan, 1: 166215. Northampton, MA: Edward Elgar.

D’Agostino, Guiseppina. 2010. Copyright, Contracts, Creators: New Media, New Rules. Cheltenham, UK: Edward Elgar.

Dalla Costa, Mariarosa, and Selma James. 1972. The Power of Women and the Subversion of the Community. Bristol: The Falling Wall Press.

De Peuter, Greig. 2010. Creative Economy Contested: Notes on Precarious Labour Politics in New York City. Paper presented at Are We All Cultural Workers Now? Getting By In Precarious Times, Centre for Cultural Research, University of Western Sydney, November 25-26.

De Peuter, Greig. 2011. Creative Economy and Labor Precarity: A Contested Convergence. Journal of Communication Inquiry 35 (4): 417-425.

De Peuter, Greig. 2012. Modelling Workers' Rights. Shameless. http://www.shamelessmag.com/stories/2012/04/modellingworkers-rights/.

Deuze, Mark. 2007. Media Work. London: Polity.

Deuze, Mark, and Leopoldina Fortunati. 2011. Atypical Newswork, Atypical Media Management. In Managing Media Work, edited by Mark Deuze, 111-120. London: Sage.

Dyer-Witheford, Nick, and Greig De Peuter. 2009. Games of Empire: Global Capitalism and Video Games. Minneapolis: University of Minnesota Press.

Ekinsmyth, Carol. 2002. Project Organization, Embeddedness and Risk in Magazine Publishing. Regional Studies 36 (3): 229-243.

Florida, Richard L. 2002. The Rise of the Creative Class: And How It's Transforming Work, Leisure, Community and Everyday Life. New York: Basic Books.

Garnham, Nicholas. 1997. Concepts of Culture - Public Policy and the Cultural Industries. In Studying Culture, 2nd ed., edited by Ann Gray and Jim McGuigan, 54-61. London: Arnold.

Gough-Yates, Anna. 2003. Understanding Women's Magazines: Publishing, Markets and Readerships. London: Routledge.

Guthrie, Marissa. 2011. CNN Cuts 50 Staff Members. The Hollywood Reporter, November 11. http://www.hollywoodreporter.com/news/cnn-cuts-50-staff-members-260737.

Hartley, John. 2005. Creative Industries. In Creative Industries, edited John Hartley, 1-40. Malden, MA: Blackwell.

Harvey, David. 1990. The Condition of Postmodernity: An Enquiry into the Origins of Cultural Change. Malden, MA: Blackwell.

Harvey, David. 1996. Justice, Nature and the Geography of Difference. Malden, MA: Blackwell.

Harvey, David. 2006. The Limits to Capital. London: Verso.

Harvey, David. 2010. A Companion to Marx's Capital. London: Verso.

Hesmondhalgh, David. 2007. The Cultural Industries. 2nd ed. London: Sage. 
Hesmondhalgh, David, and Sarah Baker. 2011. Creative Labour: Media Work in Three Cultural Industries. London: Routledge.

Hill, Kelly, and Kathleen Capriotti. 2009. A Statistical Profile of Artists in Canada. Hill Strategies Research Inc., February.

Himmelwit, Susan. 1983a. Exploitation. In A Dictionary of Marxist Thought, edited by Tom Bottomore, Laurence Harris, V.G. Kiernan and Ralph Miliband, 157-158. Cambridge, MA: Harvard University Press.

Himmelwit, Susan. 1983b. Surplus Value. In A Dictionary of Marxist Thought, edited by Tom Bottomore, Laurence Harris, V.G. Kiernan and Ralph Miliband, 472-475. Cambridge, MA: Harvard University Press.

Horowitz, Sara. The Freelance Surge Is the Industrial Revolution of Our Time. The Atlantic, September 13. http://www.theatlantic.com/business/archive/2011/09/the-freelance-surge-is-the-industrial-revolution-of-our-time/244229/

Huws, Ursula. 2003. The Making of a Cybertariat: Virtual Work in a Real World. New York: Monthly Review Press.

Huws, Ursula. 2007. Defragmenting: Towards a Critical Understanding of the New Global Division of Labour. Work Organisation, Labour \& Globalisation 1 (2): $1-4$

ILO [International Labor Office]. 2000. Symposium on Information Technologies in the Media and Entertainment Industries: Their Impact on Employment, Working Conditions and Labour-management Relations. Geneva: ILO. http://www.ilo.org/public/english/dialogue/sector/techmeet/smei00/smeir.htm

Im, Yung-Ho. 1997. Towards a Labour-Process History of Newsworkers. Javnost/The Public 41 (1): 31-48.

Kaul, Arthur J. 1986. The Proletarian Journalist: A Critique of Professionalism. Journal of Mass Media Ethics 1 (2): $47-55$.

Kingston, Paul William, and Jonathan R. Cole. 1986. The Wages Of Writing: Per Word, Per Piece, or Perhaps. New York: Columbia University Press.

Klowden, Kevin, and Anusuya Chatterjee. 2009. Writers' Strike of 2007-2008 The Economic Impact of Digital Distribution. Santa Monica, CA: Milken Institute.

Kperogi, Farooq A. 2011. Cooperation with the Corporation? CNN and the Hegemonic Cooptation of Citizen Journalism Through iReport. New Media \& Society 13 (2): 314-329.

Lacey, Liam. 2011. Screenwriting: It's a Terrible Job But Everybody Wants To Do It. The Globe and Mail, July 7 , R1.

Leadbeater, Charles, and Kate Oakley. 2005. Why Cultural Entrepreneurs Matter. In Creative Industries, edited by John Hartley, 299-311. Malden, MA: Blackwell.

Lorey, Isabell. 2009. Governmentality and Self-Precarization: On The Normalization of Cultural Producers. In Art and Contemporary Critical Practice: Reinventing Institutional Critique, edited by Gerald Raunig and Gene Ray, trans. Lisa Rosenblatt and Dagmar Fink, 187-202. London: MayFly Books.

Lorinc, John. 2005. Creators and Copyright in Canada. The Working Conditions of Creators in Quebec and Canada, Report prepared for Creators' Copyright Coalition and Droit d'auteur / Multimédia-Internet / Copyright. Accessed May $16,2012$. www.creatorscopyright.ca/documents/lorinc-beaulieu.html .

Marx, Karl. (1844) 1978a. Economic and Philosophic Manuscripts of 1884. In The Marx-Engels Reader, 2nd ed., edited by Robert C. Tucker, 594-617. New York: Norton.

Marx, Karl. (1852) 1978b. The Eighteenth Brumaire of Louis Bonaparte. In The Marx-Engels Reader, 2nd ed., edited by Robert C. Tucker, 66-135. New York: Norton.

Marx, Karl. (1888) 1978c. Theses on Feuerbach. In The Marx-Engels Reader, 2nd ed., edited by Robert C. Tucker, 143145. New York: Norton.

Marx, Karl. (1867) 1990. Capital: A Critique of Political Economy, Volume 1. London: Penguin Books.

May, Christopher. 2002. The Political Economy of Proximity: Intellectual Property and the Global Division of Information Labour. New Political Economy 7 (3): 317-342.

McGuigan, Jim. 2010. Creative Labour, Cultural Work and Individualization. International Journal of Cultural Policy 16 (3): 323-335.

McKercher, Catherine. 2009. Writing On The Margins: Precarity and the Freelance Journalist. Feminist Media Studies 9 (3): 370-374.

McRobbie, Angela. 2002. From Holloway to Hollywood: Happiness at Work in the New Cultural Economy? In Cultural Economy: Cultural Analysis and Commercial Life, edited by Paul du Gay and Michael Pryke, 97-114. London: Sage.

McRobbie, Angela. 2004. 'Everyone Is Creative': Artists as Pioneers of the new Economy? In Contemporary Culture in Everyday Life, edited by Tony Bennett and Elizabeth Silva, 186-202. Durham, UK: Sociologypress.

Mead, Rebecca. 2009. The Gossip Mill: Alloy, the Teen-Entertainment Factory. The New Yorker, October 19: 62-71.

Menger, Pierre-Michel. 1999. Artistic Labor Markets and Careers. Annual Review of Sociology 25: 541-574.

Miège, Bernard. 1989. The Capitalization of Cultural Production. New York: International General.

Mills, C. Wright. 1956. White Collar: The American Middle Classes. New York: Oxford University Press.

Moody, Kim. 1997. Workers in a Lean World. London: Verso.

Mosco, Vincent. 2003. The Transformation of Communication in Canada. In Changing Canada: Political Economy as Transformation, edited by Wallace Clement and Leah F. Vosko, 287-308. Montreal and Kingston: McGill-Queen's University Press.

Mosco, Vincent. 2009. The Political Economy of Communication, 2nd ed. London: Sage.

Mosco, Vincent, and Catherine McKercher. 2006. Editorial. Canadian Journal of Communication 31 (3): $493-497$.

Mozes, Suzanne. 2010. James Frey's Fiction Factory. New York, November 12. http://nymag.com/arts/books/features/69474/ .

Murdock, Graham. 2003. Back To Work: Cultural Labor in Altered Times. In Cultural Work: Understanding the Cultural Industries, edited by Andrew Beck, 15-36. London: Routledge.

Murphy, David. 1991. Journalists and the Labour Process: White-Collar Production Workers. In White-collar Work: The NonManual Labour Process, edited by Chris Smith, David Knights, and Hugh Willmott, 139-161. London: Macmillan.

Neff, Gina, Elizabeth Wissinger, and Sharon Zukin. 2005. Entrepreneurial Labor among Cultural Producers: 'Cool' Jobs in 'Hot' Industries. Social Semiotics 15 (3): 307-334.

Nies, Gerd, and Roberto Pedersini. 2003. Freelance Journalists in the European Media Industry. European Federation of Journalists. http://www.ifj-europe.org/pdfs/FinalReportFreelance.pdf.

Perlin, Ross. 2011. Intern Nation: How to Earn Nothing and Learn Little in the Brave New Economy. London: Verso. 
Pink, Daniel H. 2001. Free Agent Nation: How America's New Independent Workers are Transforming the Way We Live. New York: Warner.

Prickett, Sarah Nicole. 2010. SNP's Word of the Day: Precariat. Fashion. January 13. http://www.fashionmagazine.com/blogs/society/2012/01/13/snps-word-of-the-day-precariat/

PWAC [Professional Writers Association of Canada]. 2006. Canadian Professional Writers Survey: A Profile of the Freelance Writing Sector in Canada. Toronto. http://www.pwac.ca/files/PDF/PWACsurvey.pdf.

Ross, Andrew. 2000. The Mental Labor Problem. Social Text 18 (2): 1-31.

Ross, Andrew. 2001. No-Collar Labor in America's 'New Economy'. Socialist Register 37: 76-87.

Ross, Andrew. 2003. No Collar: The Human Workplace and its Hidden Costs. Philadelphia: Temple University Press.

Ross, Andrew. 2009. Nice Work If You Can Get It: Life and Labor in Precarious Times. New York: New York University Press.

Rossiter, Ned. 2006. Organized Networks: Media Theory, Creative Labour, New Institutions. Rotterdam: NAi Publishers.

Ryan, Bill. 1992. Making Capital From Culture: The Corporate Form of Capitalist Cultural Production. Berlin: Walter de Gruyter.

Scott, D.B. 2010. Rogers Syndication Practices Called Into Question by Canadian Writers Group. Canadian Magazines. October 2. http://canadianmags.blogspot.com/2010/10/rogers-syndiction-practices-called-into.html.

Semuels, Alana. 2008. Book Publisher Finds Teen Lit Adapts Well in Hollywood. Los Angeles Times, August 2. http://articles.latimes.com/2008/aug/02/business/fi-alloy2.

Smith, Chris and Alan McKinlay. 2009a. Creative Industries and Labour Process Analysis. In Creative Labour: Working in the Creative Industries, edited by Alan McKinlay and Chris Smith, 3-28. London: Palgrave Macmillan.

Smith, Chris and Alan McKinlay. 2009b. Creative Labour: Content, Contract and Control. Creative Labour: Working in the Creative Industries, edited by Alan McKinlay and Chris Smith, 29-50. London: Palgrave Macmillan.

Smythe, Ted Curtis. 1980. The Reporter, 1880-1900: Working Conditions and Their Influence on the News. Journalism History 7 (1): 1-10.

Standing, Guy. 2011. The Precariat: The New Dangerous Class. London: Bloomsbury.

Statistics Canada. 2012. Occupations in Art, Culture, Recreation and Sport. National Occupational Classification (NOC) 2011. http://www.statcan.gc.ca/cgibin/imdb/p3VD.pl?Function=getVDDetail\&db=imdb\&dis=2\&adm=8\&TVD=122372\&CVD=122373\&CPV=5\&CST=010120 $11 \& M L V=4 \& C L V=1 \& C H V D=122374$.

Story Board. 2010. Rogers Refuses to Remove Writer's Work From Yahoo. Story Board. November 30. http://www.thestoryboard.ca/?p=142.

The New Inquiry. 2012. The New Inquiry. 1, February.

Towse, Ruth. 2003. Copyright Policy, Cultural Policy and Support for Artists. In The Economics of Copyright, edited by Wendy J. Gordon and Richar Watt, 66-80. Cheltenham, UK: Edward Elgar.

Ursell, Gillian. 2000. Television Production: Issues of Exploitation, Commodification and Subjectivity in UK Television Labour Markets. Media, Culture \& Society 22 (6): 805-825.

Vosko, Leah F. 2000. Temporary Work: The Gendered Rise of a Precarious Employment Relationship. Toronto: University of Toronto Press.

Vosko, Leah F. 2006. Precarious Employment: Understanding Labour Market Insecurity in Canada. Montreal and Kingston McGill-Queen's University Press.

Vosko, Leah F. 2010. Managing the Margins: Gender, Citizenship, and the International Regulation of Precarious Employment. New York: Oxford University Press.

Wallenstein, Andrew. 2010. People Magazine iPad App Delayed by Paparazzi. The Hollywood Reporter. Accessed October 14, 2010. http://www.hollywoodreporter.com/news/exclusive-people-magazine-ipad-app-26788 .

Walters, Emma, Christopher Warren, and Mike Dobbie. 2006. The Changing Nature of Work: A Global Survey and Case Study of Atypical Work in the Media Industry. Switzerland: International Federation of Journalists. http://www.ifj.org/pdfs/lLOReport070606.pdf .

Waring, Marilyn. 1999. Counting For Nothing: What Men Value and What Women Are Worth, 2nd ed. Toronto: University of Toronto Press.

Wayne, Mike. 2003. Marxism and Media Studies: Key Concepts and Contemporary Trends. London: Pluto.

Weeks, Kathi. 2005. The Refusal of Work as Demand and Perspective. In The Philosophy of Antonio Negri: Resistance in Practice, edited by T.S. Murphy and A-K. Mustapha, 109-135. London: Pluto Press.

Winseck, Dwayne. 2010. Financialization and the 'Crisis of the Media': The Rise and Fall of (Some) Media Conglomerates in Canada. Canadian Journal of Communication 35 (3): 365-393.

Wright, Erik Olin. 1978. Intellectuals and the Class Structure of Capitalist Society. In Between Labor and Capital, edited by Pat Walker, 191-211. Montreal: Black Rose Books.

Wright, Erik Olin. 1997. Class Counts: Comparative Studies in Class Analysis. New York: Cambridge University Press.

\section{About the Author}

Nicole S. Cohen

Nicole S. Cohen is a PhD candidate in the Graduate Program in Communication and Culture at York University in Toronto, Canada, where she researches political economy of communication and labour. Her research has been published in Democratic Communiqué, Just Labour: A Canadian Journal of Work and Society, Feminist Media Studies and the Canadian Journal of Communication. 